\title{
Fungicide Sensitivity and Characterization of Cobweb Disease on a Pleurotus eryngii Mushroom Crop Caused by Cladobotryum mycophilum
}

\author{
Min Keun Kim ${ }^{1 *}$, Su Won Seuk ${ }^{1}$, Young Han Lee ${ }^{1}$, Hye Ran Kim ${ }^{2}$ and Kye Man Cho ${ }^{3}$ \\ ${ }^{I}$ Environment-Friendly Research Division, Gyeongsangnam-do Agricultural Research and Extension Service, Jinju 660- \\ 360, Korea \\ ${ }^{2}$ Korea Research Institute of Bioscience and Biotechnology, Daejeon 305-806, Korea \\ ${ }^{3}$ Department of Food Science, Gyeongnam National University of Science and Technology, Jinju 660-758, Korea
}

(Received on September 30, 2013; Revised on November 9, 2013; Accepted on November 11, 2013)

In 2009-2010, unusual symptoms were observed on Pleurotus eryngii grown in mushroom farms in Gyeongnam Province, Republic of Korea. One of the main symptoms was a cobweb-like growth of fungal mycelia over the surface of the mushroom. The colonies on the surface rapidly overwhelmed the mushrooms and developed several spores within 3-4 days. The colonized surface turned pale brown or yellow. The fruit body eventually turned dark brown and became rancid. Koch's postulates were completed by spraying and spotting using isolated strains. The phylogenetic tree obtained from the internal transcribed spacer sequence analysis showed that the isolated fungal pathogen corresponded to Cladobotryum mycophilum (99.5\%). In the fungicide sensitivity tests, the $\mathbf{E D}_{50}$ values for the isolate with respect to benomyl and carbendazim were from 0.29 to $0.31 \mathrm{ppm}$. Benzimidazole fungicides were most effective against $C$. mycophilum, a causal agent of cobweb disease in $P$. eryngii.

Keywords : Cladobotryum mycophilum, cobweb disease, fungal pathogen, fungicides, Pleurotus eryngii

Pleurotus eryngii, the king oyster mushroom, is one of the most commercially important mushrooms in Korea. $P$. eryngii was originally cultivated in northern Italy and Switzerland, where it is known locally as cardoncello (Ohga and Royse, 2004), but is now commonly cultivated in Europe, the Middle East, and North America, as well as in parts of Asia. Cultivation of $P$. eryngii on an industrial scale began in Korea in 1996, and by 2011, production of

\footnotetext{
*Corresponding author.

Phone) +82-55-254-1364, FAX) +82-55-254-1339

E-mail)goguma99@korea.kr
}

P. eryngii was estimated to be 54,820 tons. This species of mushroom accounts for more than $30 \%$ of the market of edible mushrooms in Korea. Demand for the mushroom is increasing rapidly because of its taste, excellent texture, and culinary value; however, in 2009, some commercially grown $P$. eryngii began to show symptoms similar to the fungal disease caused by Cladobotryum mycophilum in Agaricus bisporus. Several species of Cladobotryum, including $C$. dendroides, $C$. mycophilum, $C$. varium, $C$. multiseptatum, and C. verticillatum, are known to be the causal agents of "cobweb disease" in the cultivated mushroom A. bisporus and are found in mushroomgrowing countries worldwide (Adie et al., 2006; Gaze and Fletcher, 2008; Grogan and Gaze, 2000; Mckay et al., 1999). Cobweb disease was considered the most problematic disease affecting mushroom cultivation in the UK and Ireland in the 1990s, with recorded crop production losses of up to $40 \%$ because of severe spotting symptoms and early crop terminations at the height of the epidemic (Gaze, 1995; Gaze, 1996). A number of fungal and bacterial diseases, such as dry bubble disease in $A$. bitorquiscaused by Verticillium fungicola var. fungicola (Gea et al., 2003), internal stipe necrosis in A. bitorquis caused by Ewingella americana (Inglisand Burden, 1996), and bacterial soft rot in Flammulina velutipes caused by Erwinia carotovora subsp. carotovora (Okamoto et al., 1999), that result in severe damage to mushrooms have been reported, and management of these diseases is one of the major steps in the cultivation process. In P. eryngii, Kim et al. (2007) reported a bacterial soft rot disease by Pantoea sp. Cladobotryum varium was reported to be a causal agent of fungal disease in $P$. eryngii and $F$. velutipes (Kim et al., 1999; Kim et al., 1998). Recently, $C$. mycophilum has been reported as a causal agent of cobweb disease in P. eryngii in Spain and Korea (Gea and Navarro, 2011; Kim et al., 2012). In the 1980s, benzimidazole 
Table 1. List of strains used in this study.

\begin{tabular}{cccc}
\hline Isolate code & Geographic origin $^{\text {a }}$ & Molecular identification & Identity (\%) \\
\hline CN & Changnyeong County, GN & C. mycophilum & 99.0 \\
DS & Cheongdo county, GB & C. mycophilum & 99.0 \\
HA & Masan city, GN & C. mycophilum & 99.5 \\
HC & Hapcheon county, GN & C. mycophilum & 99.0 \\
JR & Hamyang county, GN & C. mycophilum & 99.0 \\
NK & Cheongdo county, GB & C. mycophilum & 99.0 \\
TOY & Goseong county, GN & C. mycophilum & 99.0 \\
\hline
\end{tabular}

${ }^{a}$ Abbreviations: GN, gyeongsangnam-do; GB, gyeongsangbuk-do.

fungicides such as benomyl, thiabendazole, carbendazim, and prochloraz manganese were effective against an isolate of Cladobotryum in a cropping experiment (Fletcher et al., 1983); however, outbreaks became more frequent, and reached epidemic proportions in 1994 and 1995 in the UK. Fletcher and Jaffe (1993) reported that 14 Cladobotryum isolates from British mushroom farms were still capable of growth when thiabendazole was applied at concentrations of 2 and $20 \mathrm{ppm}$. A survey of cobweb isolates from British mushroom farms in 1995 established that under in vitro conditions, $25 \%$ of isolates tested were sensitive to thiabendazole and carbendazim, while $75 \%$ were resistant, although carbendazim was still inhibitory at high concentrations (McKay et al., 1998). Because of the commercial importance of the king oyster mushroom in Korea, this study was carried out to characterize the symptoms of the disease and provide information on the efficacy of several fungicides in controlling cobweb disease on P. eryngii.

\section{Materials and Methods}

Fungal isolation and identification. Diseased fruitbodies of $P$. eryngii were collected at five mushroom farms in Gyeongnam and Gyeongbuk Provinces (Korea) between 2009 and 2010. The infected regions were washed carefully, soaked for $5 \mathrm{~min}$ in $1.0 \% \mathrm{NaOCl}$ solution, rinsed with sterile distilled water, placed on potato dextrose agar (PDA) plates, and incubated at $25^{\circ} \mathrm{C}$ for 7 days. After incubation, the colonies that grew on the plates were cut into $1-\mathrm{cm}$ segments and transferred to fresh PDA. To preserve the cultures, the mycelia and conidia from wild strains were transferred to $1 \mathrm{ml}$ sterilized mineral oil (Sigma, St. Louis, USA) solution and stored at $4^{\circ} \mathrm{C}$ to observe their cultural and microscopic characteristics. All of isolates used in this study are listed in Table 1.
DNA extraction. The isolate was grown in $100 \mathrm{ml}$ potato dextrose broth (PDB) in 250-ml Erlenmeyer flasks incubated at $25^{\circ} \mathrm{C}$ for 7 days. Mycelial mats were collected by vacuum filtration, washed with sterilized double-distilled water, and allowed to air dry. The sample was finely ground with a mortar. Genomic DNA was extracted from $30 \mathrm{mg}$ of fungal tissue using the i-genomic BYF DNA Extraction Mini Kit (iNtRON Biotechnology, Korea) according to the manufacturer's protocol for DNA isolation. The genomic DNA was quantified by Nano-Drop 1000 (Thermo Fisher Scientific Inc., München, Germany).

Amplification of internal transcribed spacers 1 and 2 and 5.8S rDNA regions. The internal transcribed spacer (ITS) region of rDNA in the isolated strain was amplified by polymerase chain reaction (PCR) using universal primers ITS 1 (5'-TCCGTAGGTGAACCTGCG-3') and ITS4 (5'-TCCTCCGCTTATTGATATGC-3'). Amplification reactions were performed in a total volume of $50.0 \mu \mathrm{l}$ containing $5.0 \mu \mathrm{l} 10 \times$ PCR buffer, $4.0 \mu \mathrm{l} 2.5$ $\mathrm{mM}$ dNTP, $8.0 \mu \mathrm{l}$ of each primer $(1 \mathrm{pmol} / \mu \mathrm{l}), 0.5 \mu \mathrm{l}$ Taq DNA polymerase, $5.0 \mu \mathrm{l}$ genomic DNA $(10 \mathrm{ng} / \mu \mathrm{l})$, and $19.5 \mu \mathrm{l}$ sterilized double-distilled water. The reactions were performed using a thermocycler (PTC-200, MJ Research Inc., Watertown, USA), according to the following program: 1 cycle at $94^{\circ} \mathrm{C}$ for $5 \mathrm{~min} ; 35$ cycles at $94^{\circ} \mathrm{C}$ for $30 \mathrm{~s}, 52^{\circ} \mathrm{C}$ for $30 \mathrm{~s}$, and $72^{\circ} \mathrm{C}$ for $1 \mathrm{~min}$; and 1 cycle at $72^{\circ} \mathrm{C}$ for $10 \mathrm{~min}$.

Sequencing of PCR products. Amplification products were analyzed by gel electrophoreses on a $1.5 \%$ agarose gel with a 1-Kb DNA Plus Ladder (Bioneer, Korea) as a marker. The purified PCR product was ligated into a pGEM-T easy vector (Promega, Madison, USA) and transformed into competent Escherichia coli DH5a cells. Nucleotide sequencing was performed using the dideoxy-chain 
termination method using the PRISM Ready Reaction Dye terminator/primer cycle sequencing kit (Perkin-Elmer Corp., Norwalk, USA). The samples were analyzed using an automated DNA sequencer (Model 3100; Applied Biosystems, Foster City, USA). The sequence data from the isolate were deposited in GenBank under the Accession No. JF693809.

DNA sequence analysis. The GenBank databases were used for similarity searches using BLAST (National Center for Biotechnology Information [NCBI], U.S. National Institutes of Health, Bethesda, USA). The ITS sequence was aligned for phylogenetic analysis using Cluster W (Thompson et al., 1994). The phylogenetic tree was constructed by the neighbor-joining method using DNAMAN (Lynnon Biosoft, Canada). Bootstrap analysis was repeated 1,000 times to examine the reliability of the interior branches and the validity of the trees obtained (Felsenstein, 1985; Saitou and Nei, 1987).

Microscopic analysis. The isolated pathogenic fungus grown on PDA was examined microscopically. The morphological structures of the conidia and mycelium were observed by scanning electron microscopy (VT1420; Carl Zeiss Inc., Germany). For microscopic analysis of conidial germination, conidia were harvested from the water of a 12-day-old PDA medium and passed through sterile cheesecloth to remove the mycelial fragments. The conidia were washed once with sterilized water by centrifugation, resuspended in water at $2 \times 10^{5} / \mathrm{ml}$, inoculated on PDB, and incubated in stationary phase at $25^{\circ} \mathrm{C}$ for $24 \mathrm{~h}$. The specimen was mounted hourly on a slide glass and visualized using a transmitted light microscope in phase contrast (IX71; Olympus, Tokyo, Japan).

Pathogenicity tests. The strain that was tested for pathogenicity was grown on PDA at $25^{\circ} \mathrm{C}$ for $24 \mathrm{~h}$. The inoculum was prepared by flooding the agar surface with $10 \mathrm{ml}$ sterilized double-distilled water and scraping it with a spatula. The resulting spore suspension was filtered through three layers of cheesecloth. The filtrate was diluted with sterilized double-distilled water, and the conidial concentration was adjusted using a hemacytometer to $1 \times 10^{6}$ conidia $/ \mathrm{ml}$. A conidial suspension was inoculated onto each stage of mushroom cultivation using a pipette. The control was spotted with double-distilled water. The experiment was repeated a minimum of three times.

Test for sensitivity to fungicides. Benomyl 50\% WP (Dongbu benomyl, Dongbu Farm, Seoul, Korea), Carbendazim 60\%
WP (Dongbu gabenda, Dongbu Farm, Korea), prochloraz manganese 50\% WP (Sporgon, Hankook Samgong Co., Ltd, Korea), chlorothalonil 75\% WP (Daconil, Kyung Nong Co., Ltd, Korea), and thiophanate-methyl 70\% WP (Topsin M, Kyung Nong Co., Ltd, Korea) were used as active ingredients in this study. Both benomyl and carbendazim are benzimidazole fungicides that bind to fungal beta-tubulins and inhibit microtubule function. Prochloraz manganese is a sterol C-14 demethylation inhibitor that impairs the biosynthesis of ergosterol, an essential compound for the stability and functioning of lipoprotein membranes (Hassall, 1990). Freshly-prepared stock solutions were used to provide specific concentrations of active ingredients in ppm. Volumes of stock solution were added to molten sterile culture media before pouring, giving active ingredient concentrations ranging from 0.1 to $100 \mathrm{ppm}$ depending on the experiment. An agar plug of each isolate was placed in the center of each agar plate containing fungicide and incubated. Colony size across two diameters was measured for each plate after 7 days in the dark at $25^{\circ} \mathrm{C}$. The fungicide sensitivity of each isolate was estimated from the $\mathrm{ED}_{50}$ values (ppm concentration inhibiting radial mycelia growth by $50 \%$ ). $\mathrm{ED}_{50}$ values were determined for each isolate by interpolation from computer-generated log-probit plots of fungicide concentration and relative inhibition.

\section{Results}

Symptoms. In 2009, unusual symptoms were observed in P. eryngiigrown in mushroom farms in Gyeongnam and Gyeongbuk Province (Fig. 1). The mycelium of the fungal pathogen surrounded the fruit bodies and covered the plastic bottle containing the substrates in the early stages of growth. One of the main symptoms was a cobweb-like growth of fungal mycelium over the surface of the mushrooms. The colonies on the surface rapidly overwhelmed the mushrooms and developed several spores within 3-4 days. The colonized surface turned pale brown or yellow. In some instances, the infected mushrooms were reddish, accompanied by cracking of the stipe surface. The fruit body eventually turned dark brown and became rancid.

Isolate identification. The colonies grew as rapidly as 20 to $30 \mathrm{~mm}$ per day on the PDA plates. The colonies of the isolates on the PDA were yellowish, and a reddish color or orange was evident in the normally transparent agar plate (Fig. 2). The optimal temperature used was $25^{\circ} \mathrm{C}$ and the $\mathrm{pH}$ level was set at between 6 and 7 . Under 

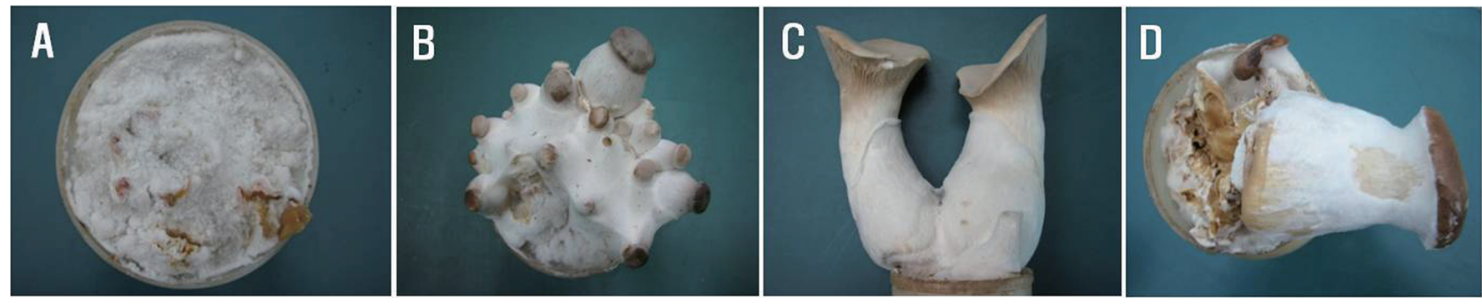

Fig. 1. Cobweb symptoms of naturally infected Pleurotus eryngii by Cladobotryum mycophilum. (A) Primordial formation stage. (B) Early growing stage. (C and D) Harvesting stage.

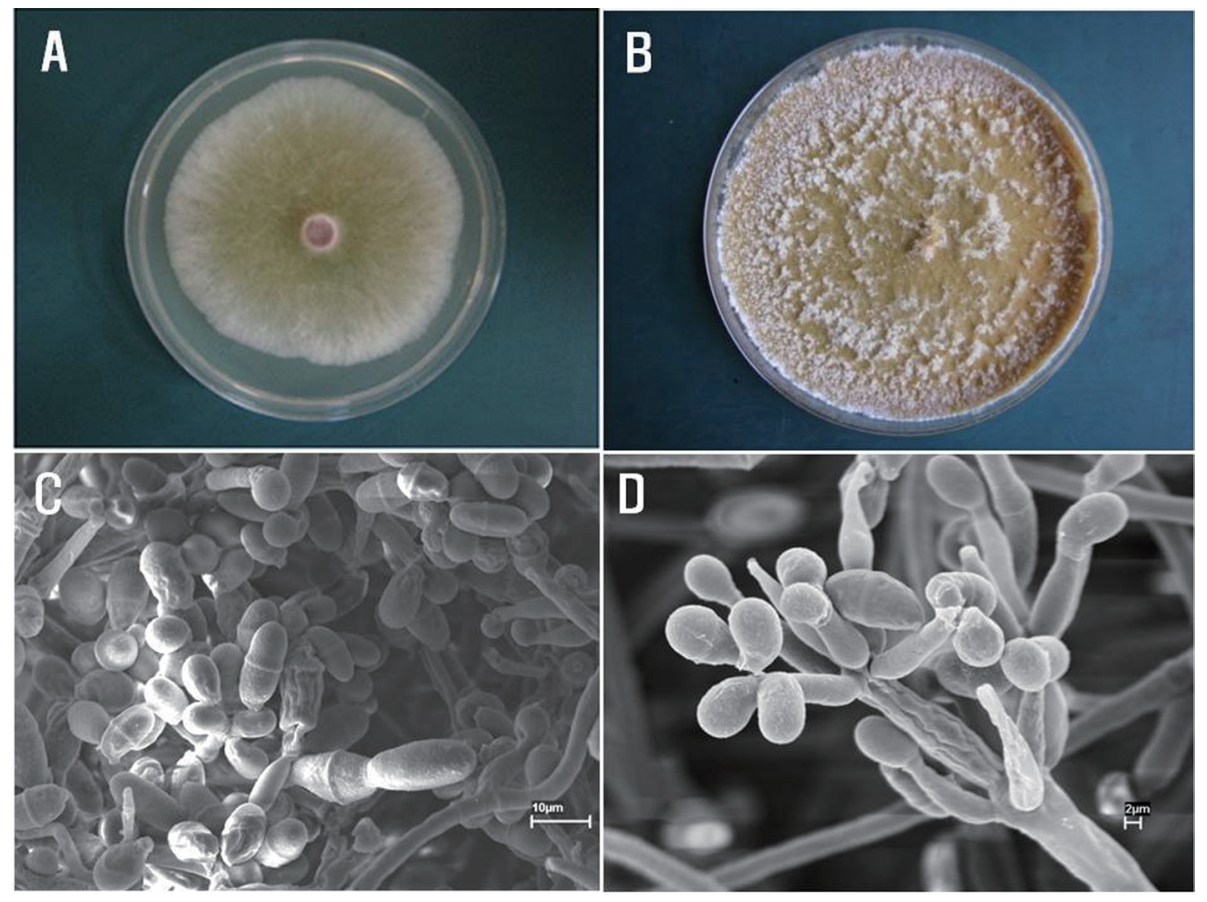

Fig. 2. Morphological characteristics and scanning electron micrographs of Cladobotryum mycophilum isolated from the diseased fruitbodies. (A and B) Mycelia and colony at $25^{\circ} \mathrm{C}$ on PDA on petri dishes $(87 \mathrm{~cm})$. (C and D) Conidia (original magnification $\left.\times 3,000\right)$ and conidiophores (original magnification $\times 4,000$ ).

these conditions, the conidia were able to germinate and grow in $4 \mathrm{~h}$ (Fig. 3). Microscopically, large spores with a single septum were produced on vertically branched conidiophores bearing 2 to 4 , mostly 3 to 4 , sporogenous cells, ranging from 17.2 to $20.5 \mathrm{~m}$ long and from 8.0 to $10.2 \mu \mathrm{m}$ thick. The shape of the conidia was ellipsoid and obovoid (Fig. 2).

ITS sequence analysis. To identify the isolated fungal pathogens, the ITS region was amplified using ITS1 and ITS4 primers and then sequenced. The sizes of the ITS1 and ITS2 regions were 172 and $190 \mathrm{bp}$, respectively. The ITS sequences of the isolates were $99.0 \%$ identical to each other, and were compared with those of other related strains from GenBank. A BLAST search showed that all of isolated strains belonged to a species of Cladobotryum. The highest similarity $(99.5 \%)$ was to the ITS sequence of C.mycophilum (Y17096). The phylogenetic tree based on the nucleotide sequence of the ITS region was obtained using the neighbor-joining method. A bootstrap analysis with 1,000 replications was performed to determine support for various clades. The phylogenetic tree obtained from the ITS sequence analysis indicated that the isolated fungal pathogen corresponded to C. mycophilum (Fig. 4).

Pathogenicity test. Mushroom cultivation can be divided into the following steps: spawn running, regeneration after scratching, primordia formation, growing, and harvesting. Artificial infection was induced using an isolate of $C$. mycophilum during the five stages of $P$. eryngii cultivation. 

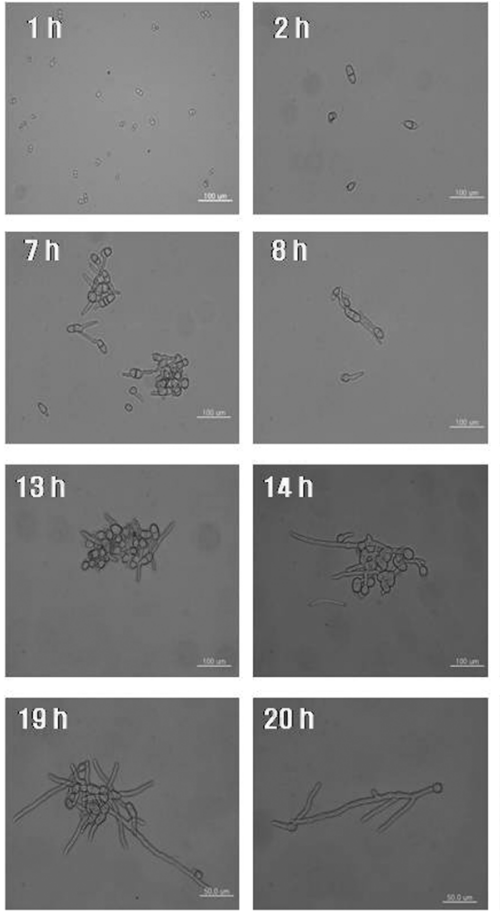
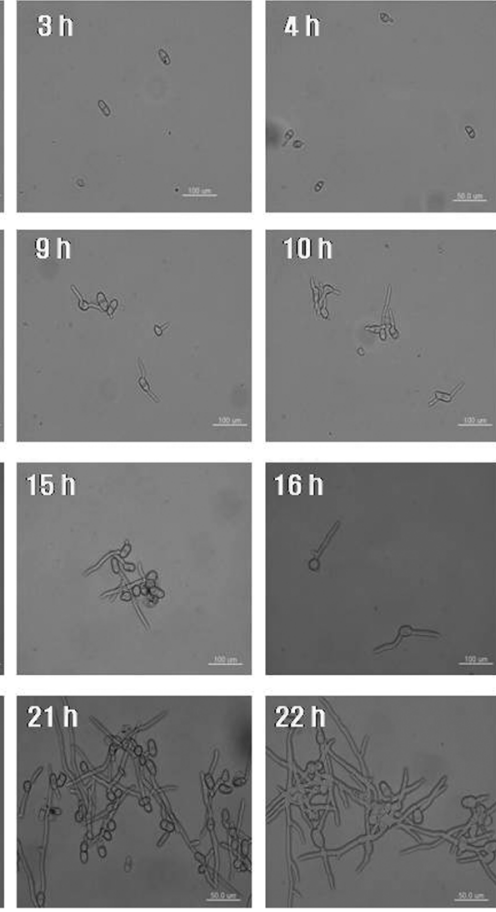
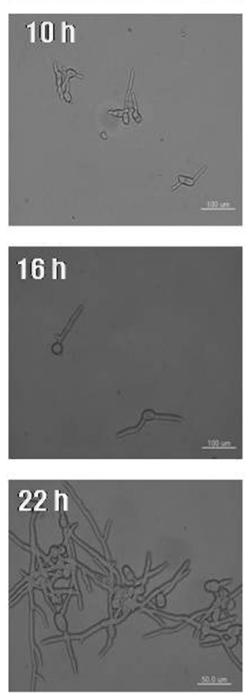
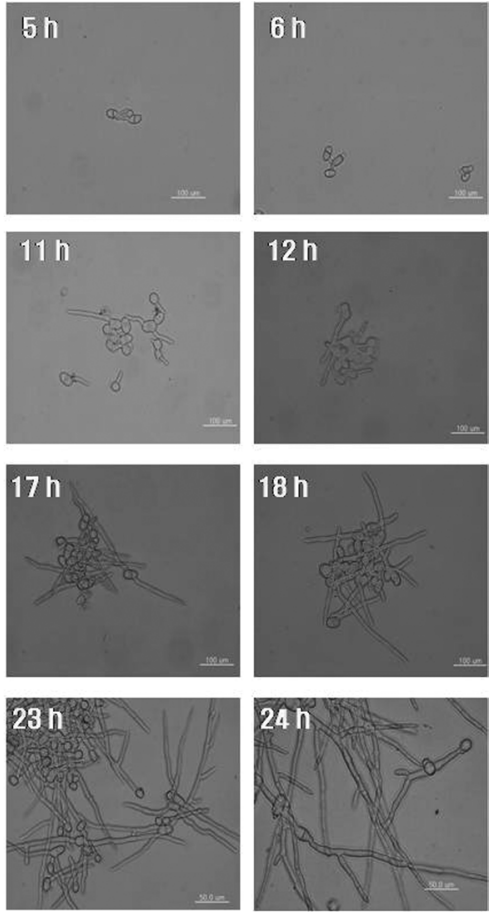

Fig. 3. Light micrographs of conidia germination. The incubation time is shown in the micrograph. The conidia were cultured to stationary phase at $25^{\circ} \mathrm{C}$ on PDB for $24 \mathrm{~h}$. Scale bar, 50 or $100 \mu \mathrm{m}$.

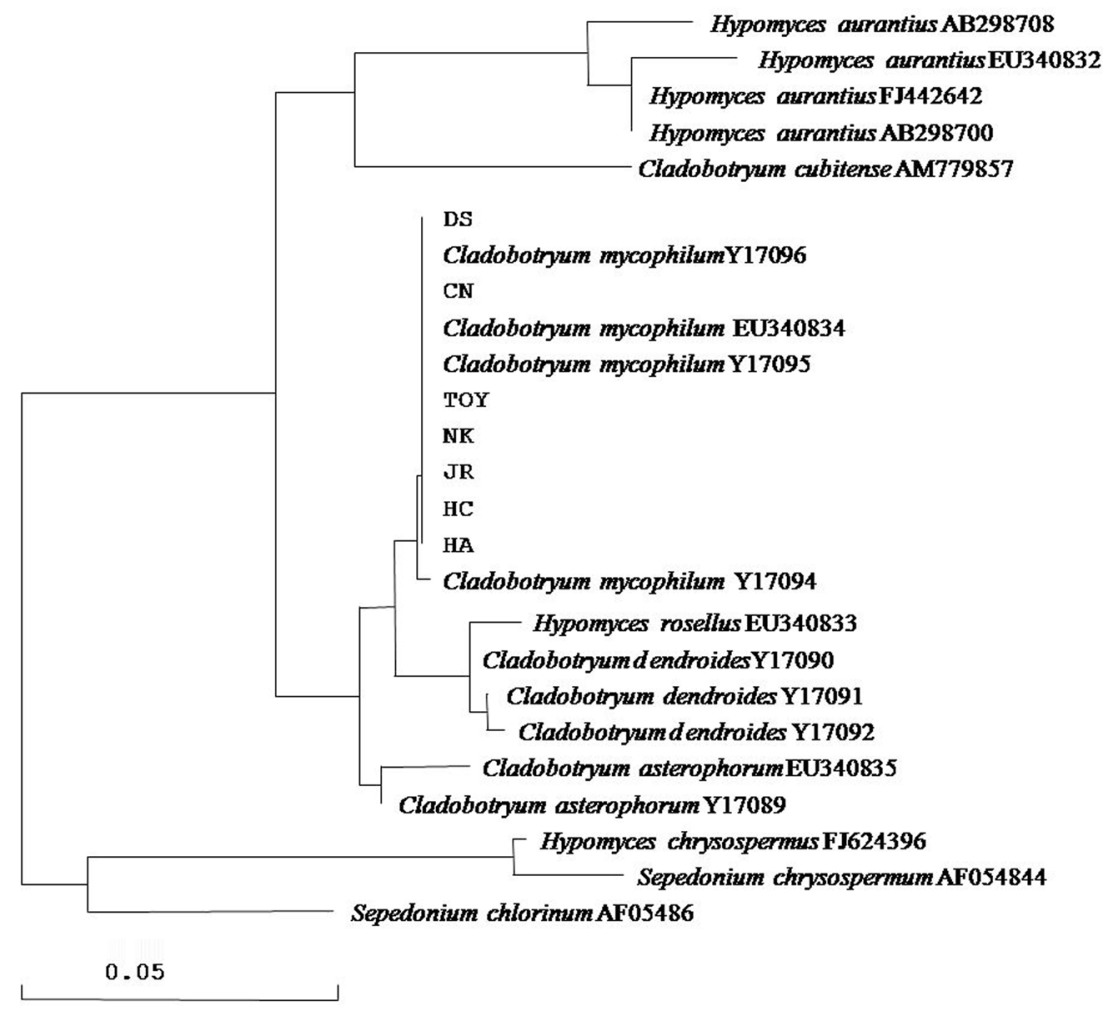

Fig. 4. Phylogenetic distance tree constructed by the neighbor-joining method comparing the internal transcribed spacer region sequences of the isolated strains with those of other Cladobotryum species from GenBank. The scale bar represents genetic distance. 

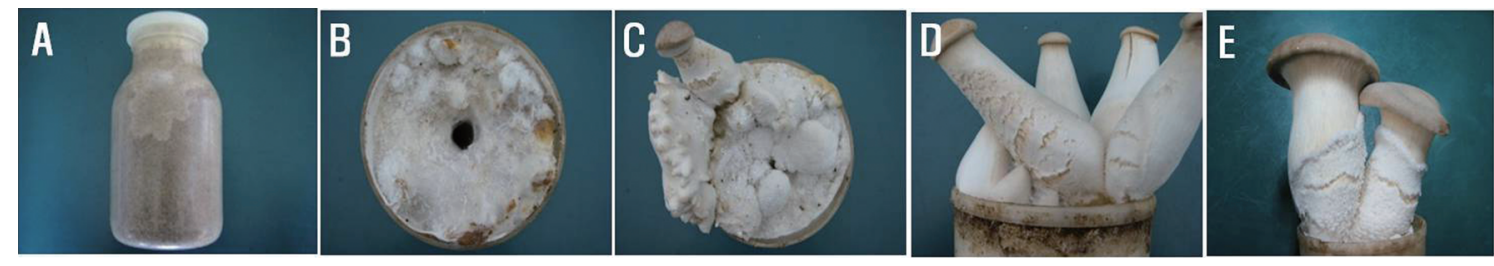

Fig. 5. Symptoms of cobweb disease caused by artificial inoculation in Pleurotus eryngii. (A) Spawn running stage. (B) Regeneration stage after scratching. (C) Primordial formation stage. (D) Growing stage. (E) Harvesting stage.

Conidial suspensions of the isolate were prepared from PDB cultures grown at $25^{\circ} \mathrm{C}$ for $4 \mathrm{~h}$ and inoculated using the pipetting method. When infected during the inoculation and spawn running stages, the fungal mycelia covered the media and hampered mycelial development in the $P$. eryngii specimens. When infected during the regeneration and primordial formation stages, the mycelium of the fungal pathogen covered the surface of the plastic bottle containing the substrates and developed several spores. In the growing and harvesting stages, the surface of the mushroom was overwhelmed by the mycelium of the fungal pathogen and turned pale or dark brown, accompanied by cracking of the stipe surface (Fig. 5). The fungal pathogens can attack $P$. eryngii at any cultivation stage. The symptoms of the cobweb-like disease were observed within 5 to 7 days after inoculation with conidial suspensions of $C$. mycophilum. The symptoms were similar to those observed in mushroom farms, initially covering the surface of the fruit body, which later becomes pale or dark brown, accompanied by cracking of the stipe surface, and finally rotting with an offensive odor. The causal fungi were re-isolated from lesions on the substrate and the fruit body. The fungi isolated from the inoculated mushrooms were shown to be identical, based on phenotypic characteristics, to the inoculated strain used in these pathogenicity tests. These results showed that the disease symptoms could be reproduced and the fungi could be reisolated, thus satisfying Koch's postulates (Falkow, 1988).

Fungicide sensitivity. To assess inhibition of mycelial growth of the fungal pathogen by selected fungicides (benomyl, prochloraz manganese, carbendazim, chlorothalonil, and thiophanate-methyl), the isolate was divided into three groups: the sensitive, the intermediate resistant, and the resistant. Each group was differentiated by the concentration of fungicide necessary to cause inhibition; the sensitive group showed sensitivity to concentrations $<1.0 \mathrm{ppm}$, the moderately sensitive group was sensitive to concentrations between 2.0 and $8.0 \mathrm{ppm}$, and the resistant group was sensitive to concentrations $>10.0 \mathrm{ppm}$ (Table 2 ). The fungal pathogen is sensitive to both benomyl and carbendazim as well as moderately sensitive to prochloraz manganese and thiophanate-methyl. Although the isolate was inhibited at a concentration $\geq 10.0 \mathrm{ppm}$, it was resistant to chlorothalonil. Benomyl and carbendazim were the most effective against C.mycophilum, a causal agent of cobweb disease in P. eryngii. The $\mathrm{ED}_{50}$ values for the isolate with respect to benomyl and carbendazim were from 0.29 to 0.31 ppm.

\section{Discussion}

The C. mycophilum was the predominant species isolated from the diseased mushroom of $P$. eryngii in the different regions of Gyeongnam Province, Korea, with symptoms very similar to those of cobweb disease, which is a serious fungal disease in A. bisporus (Adie et al., 2006; Mckay et al., 1999). The causal agent of cobweb disease is known to be species of Cladobotryum, including C. multiseptatum, C. mycophilum, C. varium, and C. verticillatum in $A$. bisporus and $F$. velutipes, which have been observed by various authors in cultivated mushrooms (De Hoog, 1978; Kim et al., 1999; Mckay et al., 1999; Sharma et al., 1992; Sinden 1971). Recently, C. mycophilum has been

Table 2. The inhibitory effect of specific fungicides on the radial growth of Cladobotryum mycophilum on PDA at $25^{\circ} \mathrm{C}$

\begin{tabular}{|c|c|c|c|c|c|c|}
\hline \multirow{2}{*}{$\begin{array}{l}\text { Radial growth } \\
\text { (mm/day) }\end{array}$} & & \multicolumn{5}{|c|}{ Inhibitory concentration (mg/kg) } \\
\hline & & Benomyl & Carbendazim & Prochloraz manganese & Thiophanatemethyl & Chlorothalonil \\
\hline \multirow{2}{*}{$24.6 \pm 1.6^{\mathrm{a}}$} & $\mathrm{ED}_{50}$ & 0.29 & 0.31 & 1.69 & 2.65 & 4.40 \\
\hline & $\mathrm{ED}_{90}$ & 0.38 & 0.48 & 5.02 & 4.01 & 14.76 \\
\hline
\end{tabular}

${ }^{\mathrm{a}}$ Values are mean \pm S.D. 
reported as a causal agent of cobweb disease in A. bisporus and P. eryngii in Korea and Spain (Back and Kim, 2010; Gea and Navarro 2011; Kim et al., 2012). In this study, a white fungus surrounding the fruit body was isolated from $P$. eryngii having disease symptoms. We confirmed the identity of the isolated strain by morphological criteria and sequencing analysis of the ITS region. This fragment was $99.5 \%$ homologous with a sequence derived from the C. mycophilum (Y17096) sequence data available in the NCBI database. A Cladobotryum colony releases a mass of conidia that causes the cobweb disease if they land on the stipes and the caps of mushrooms (Adie et al., 2006). The spores are relatively large and multicellular and are easily dislodged from the sporulating colony by external disturbances such as watering, air circulation systems, and harvesting (Dar, 1997). The conidia were able to germinate and grow in $4 \mathrm{~h}$. This fact suggests that the spores are very readily dispersed in the air. Air-borne spores from affected crops might contaminate reusable plastic bottles, substrates, and transportation systems, and the pathogen could rapidly spread from farm to farm. This is the main mode of transmission by which the pathogen is distributed to mushroom farms. The ITS analysis of the causal agents collected from the various mushroom farms showed a similarity among each agent higher than $99.0 \%$ (data not shown). This result supports the idea that the rapid distribution and growth of conidia are important causative factors of cobweb disease in $P$. eryngii. On the basis of the pathogenicity test results, the pathogen could also attack $P$. eryngii at any cultivation stage, making it a potentially serious fungal pathogen of this species. In the sensitivity test of mycelial growth of the fungal pathogen, the isolate was well controlled by both benomyl and carbendazim. These results showed that the isolate was sensitive to benzimidazole fungicides in vitro; therefore, benomyl and carbendazim would be the fungicides of choice to control the cobweb disease caused by $C$. mycophilum. Even so, continued use of the benzimidazole fungicides would increase the selection pressure on existing sensitive populations. To reduce this risk, benomyl and carbendazim should be used with caution only when mushroom growers know for certain that the pathogen they wish to control is sensitive to benzimidazole. In addition, complex of the active ingredient with prochloraz manganese and thiophanate-methyl might help to prevent or at least decrease the risk of the pathogen becoming resistant. These data provide some understanding of the causal agent of a fungal disease in P. eryngii. Further research is needed on the attack mechanism of the pathogen against its host and the development of effective disease control using biological methods on mushroom farms.

\section{Acknowledgment}

This work was supported by the Mushroom Export Research Program, Ministry for Food, Agriculture, Forestry and Fisheries, Republic of Korea (Project no. 608005-05-5HD360).

\section{References}

Adie, B., Grogan, H., Archer, S. and Mills, P. 2006. Temporal and spatial dispersal of Cladobotryum conidia in the controlled environment of a mushroom growing room. Appl. Environ. Microbiol. 72:7212-7217.

Back, C. G. and Kim, Y. H. 2010. Cobweb disease on Agaricus bisporus caused by Cladobotryum mycophilum in Korea. $J$. Gen. Plant Pathol. 76:232-235.

Dar, G. M. 1997. Studies on the dispersal of cobweb disease of cultivated white button mushroom. Res. Dev. Reporter 14:4348.

De Hoog, G. S. 1978. Notes on some fungicolus hyphomycetes and their relatives. Persoonia 10:33-81.

Falkow, S. 1988. Molecular Koch's postulates applied to microbial pathogenicity. Rev. Infect. Dis. 10:274-276.

Felsenstein, J. 1985. Confidence limits on phylogenies: an approach using the bootstrap. Evolution. 39:783-91.

Fletcher, J. T. and Jaffe, B. 1993. Mushrooms-fungicide resistance. Horticultural Development Council Research Report M14. Kent, ME19DZ, UK, Bradbourne House.

Fletcher, J. T., Hims, M. J. and Hal, R. J. 1983. The control of bubble diseases and cobweb disease of mushrooms with prochloraz. Plant Pathol. 32:123-131.

Gaze, R. H. 1995. Dactylium or cobweb. Mushroom J. 546:2324.

Gaze, R. H. 1996. The past year. Mushroom J. 552:24-25.

Gaze, R. H. and Fletcher, J. T. 2008. Mushroom pest and disease control: a color handbook. SD, USA, Academic Press.

Gea, F. J., Tello, J. C. and Navarro, M. J. 2003. Occurrence of Verticillium fungicola var. fungicola on Agaricus bitorquis mushroom crops Spain. J. Phytopathol. 151:98-100.

Grogan, H. M. and Gaze, R. H. 2000. Fungicide resistance among Cladobotryum spp. causal agents of cobweb disease of the edible mushroom Agaricus bisporus. Mycol. Res. 104:357364.

Hassall, K. A. 1990. The Biochemistry and Uses of Pesticides. Weinheim, Cambridge, UK, 536 pp.

Inglis, P. W. and Burden, J. F. 1996. Evidence for the association of the enteric bacterium Ewingella americana with internal stipe necrosis of Agaricus bisporus. Microbiology 142: 32533260.

Kim, H. K., Seok, S. J., Kim, G. P., Moon, B. J. and Terashita, T. 1999. Occurrence of disease caused by Cladobotryum varium on Flammulina velutipes in Korea. Korean J. Mycol. 27:415419. 
Kim, M. K., Ryu, J. S., Lee, Y. H. and Yun, H. D. 2007. First report of Pantoea sp. induced soft rot disease of Pleurotus eryngii in Korea. Plant Dis. 91:109.

Kim, T. S., Lee, H. W., Song, G. W. and Shin, W. G. 1998. King oyster mushroom (Pleurotus eryngii) white mold disease caused by Cladobotryum varium. KSM News Lett 11:46.

McKay, G. J., Egan, D., Morris, E. and Brown, A. E. 1998. Identification of benzimidazole resistance in Cladobotryum dendroides using a PCR-based method. Mycol. Res. 102:671676.

Mckay, G. J., Egan, D., Morris, E., Scott, C. and Brown, A. E. 1999. Genetic and morphological characterization of Cladobotryum species causing cobweb disease of mushrooms. Appl. Environ. Microbiol. 65:606-610.

Ohga, S. and Royse, D. J. 2004. Cultivation of Pleurotus eryngii on umbrella plant (Cyperus alternifolius) substrate. J. Wood Sci. 50:466-469.

Okamoto, H., Sato, M. and Isaka, M. 1999. Bacterial soft rot of winter mushroom and oyster mushroom caused by Erwinia carotovora subsp. carotovora. Ann. Phytopathol. Soc. Jpn. 65: 460-464.

Saitou, N. and Nei, M. 1987. The neighbor-joining method: a new method for reconstructing phylogenetic tree. Mol. Biol. Evol. 4:406-425.

Sharma, V. P., Suman, B. C. and Guleria, D. S. 1992. Cladobotryum verticillatum a new pathogen of Agaricus bitorquis (Que'1.) Sacc. Indian J. Mycol. Plant Pathol. 22:62-65.

Sinden, J. W. 1971. Ecological control of pathogens and weed moulds in mushroom culture. Annu. Rev. Phytopathol. 9: 411-432.

Thompson, J. D., Higgins, D. G. and Gibson, T. J. 1994. Clustal W: improving the sensitivity of progressive multiple sequence alignment through sequence weighting, position-specific gap penalties and weight matrix choice. Nuc. Acids Res. 22: 4673-4680. 